\title{
PIGMENTED LESIONS OF THE SKIN- A ONE-YEAR STUDY AT TERTIARY CARE CENTRE
}

\author{
Zaheda Kauser1, Naga Kalyani Pathuri², Anunayi Jeshtadi3, Durga $K^{4}$
}

${ }_{1}^{1}$ Assistant Professor, Department of Pathology, Osmania Medical College, Hyderabad, Telangana, India. ${ }^{2}$ Assistant Professor, Department of Pathology, Osmania Medical College, Hyderabad, Telangana, India.

${ }^{3}$ Associate Professor, Department of Pathology, Osmania Medical College, Hyderabad, Telangana, India. ${ }^{4}$ Professor and HOD, Department of Pathology, Osmania Medical College, Hyderabad, Telangana, India.

\section{BACKGROUND} ABSTRACT

Melanocytic proliferations are commonly known as pigmented lesions and they are usually benign (90\%), also called as Moles or Nevi. Malignant proliferations melanomas account for about $10 \%$. Histopathological interpretation of these lesions is useful to differentiate non-neoplastic pigmented lesions from neoplastic pigmented lesions. Non-neoplastic pigmented lesions include seborrheic keratosis and pigmented actinic keratosis. Neoplastic pigmented lesions include pigmented basal cell carcinoma and malignant melanoma. Malignant transformations can be prevented by early removal of premalignant lesions.

Aim- To study all the pigmented lesions, both melanocytic and non-melanocytic, with respect to their clinical features and histopathological findings.

\section{MATERIALS AND METHODS}

A retrospective case series study was conducted at Osmania General Hospital, Hyderabad, over a period of 1 year (Jan. 2017 - Dec. 2017) on all clinically pigmented lesions that were biopsied or excised. All lesions were analysed with respect to their important clinical and histological features. IHC was carried out using HMB-45 and S-100 where indicated.

\section{RESULTS}

A total of 31 cases were studied. The mean age for benign pigmented lesions was 25 years and male-to-female ratio of 1.2: 1. Mean age for melanomas was 60 years with female preponderance. Majority of the lesions were located on head and neck region. In this study, the commonest benign pigmented lesion was melanocytic nevi and pigmented basal cell carcinoma and melanoma among malignant lesions.

\section{CONCLUSION}

Early diagnosis of pre-malignant pigmentary lesions of the skin and surgical removal helps to prevent occurrence of malignant disease.

\section{KEY WORDS}

Melanocytic Proliferation, Malignant Melanoma, Nevi, Pigmented Basal Cell Carcinoma.

HOW TO CITE THIS ARTICLE: Kauser Z, Pathuri NK, Jeshtadi A, et al. Pigmented lesions of the skin- a one-year study at tertiary care centre. J. Evolution Med. Dent. Sci. 2018;7(41):4411-4414, DOI: 10.14260/jemds/2018/985

\section{BACKGROUND}

Skin cancer is the most common human cancer. One of the useful measures to prevent skin cancer is early diagnosis of precancerous skin lesions. Some non-neoplastic lesions such as solar keratosis of the skin are so clearly associated with cancer that are known as precancerous states. Melanocytic proliferations are composed of one or more of three related cell types: melanocytes, nevus cells or melanoma cells, each of which may be located in the epidermis or the dermis.[1]

Melanocytic nevi are benign tumours, while malignant melanomas are malignant tumours. Melanocytic lesions are important as malignant melanoma, which accounts for only $4 \%$ of skin cancers, is responsible for over $60 \%$ of cancer related deaths. The number of melanoma cases is increasing faster than any other cancers according to World Health Organization. [2]

'Financial or Other Competing Interest': None.

Submission 12-09-2018, Peer Review 25-09-2018,

Acceptance 27-09-2018, Published 08-10-2018.

Corresponding Author:

Dr. Naga Kalyani Pathuri,

H. No. 16-3-989/c,

Near Police Hospital, Malakpet,

Hyderabad-500024, Telangana, India.

E-mail: kalyani.pathuri@gmail.com

DOI: $10.14260 /$ jemds/2018/985
All the pigmented lesions are assessed for being potentially malignant by ABCDE mnemonic which takes into account asymmetry, border irregularities, colour variation, diameter $>5 \mathrm{~mm}$ and evolution. ${ }^{[3,4]}$ Risk factors for malignant melanocytic lesions are both genetic and environmental, specially sunlight exposure in light coloured skin people, family history of melanomas, presence of multiple melanocytic nevi, xeroderma pigmentosum and dysplastic nevi. Early diagnosis helps in early treatment of the disease and decreased mortality rate. Melanocytic nevi appear in adolescence and early adulthood rarely present at birth. They are believed to start out as junctional nevi, then compound nevi and having become intradermal nevi undergo involution.

Rene Laennec in 1806 gave the first description of melanoma as a disease entity. The peak incidence of melanoma is around the $6^{\text {th }}$ decade of life. Predominantly, they are associated with sunlight exposure. Therefore, most are found in the head and neck area and lower extremity, the latter being particularly common in females. ${ }^{[5]}$

Nevus sebaceous of Jadassohn or verrucous epidermal nevi, is a hamartomatous lesion expressing elements of sebaceous and apocrine glands, defective hair follicles, acanthosis and papillomatosis. It is a congenital lesion, usually present on the scalp and face. The lesion tends to enlarge with time. The malignant potential of this lesion has been estimated to be $10-50 \%$. Degeneration into basal cell 
carcinoma is most common.

Seborrheic keratosis (SK) is also known as seborrheic wart, senile wart and basal cell papilloma. It is a benign, noninvasive, hyperplastic epidermal lesion. It is the most common benign skin lesion found predominantly in middle aged or elderly. As they become old they may progress to become dark brown or black, which can be confused with melanoma. In spite of its melanotic appearance it can be differentiated from a melanoma by its elevated position, distinct border and greasy appearance. About $6 \%$ of all basal cell carcinomas are pigmented, which has similar features to nodular basal cell carcinoma except for increased melanisation.

Becker's nevus (Melanosis) is an acquired melanosis that presents in late childhood or early adolescence. An hyperpigmented patch gradually evolves into a plaque and usually displays variable degree of hypertrichosis. It typically arises in the vicinity of the large joints especially shoulders, elbows and hips.

World Health Organization histological classification of melanoma includes superficial spreading, nodular, lentigo maligna, acral lentiginous, desmoplastic melanoma arising from blue nevus and those arising in giant congenital naevi, childhood, naevoid and persistent melanoma. Almost all the types of melanomas originate from melanocytes at epidermodermal junction. The concept of radial and vertical growth phase in the evolution of malignant melanoma was introduced by Clark et al.[6]

\section{Clark's Level of Invasion}

1. Level 1- Confined to dermis.

2. Level 2- Invasion into papillary dermis.

3. Level 3- Invasion into papillary and reticular dermis interphase.

4. Level 4- Invasion into reticular dermis.

5. Level 5- Invasion into subcutaneous fat.

\section{Objective}

To study all the pigmented skin lesions, both melanocytic and non-melanocytic by histopathological examination and clinical findings, to differentiate between premalignant, nonneoplastic and pigmented malignant lesions of the skin.

\section{MATERIALS AND METHODS}

This is a retrospective case series study. All the clinically pigmented skin lesions that were biopsied were studied retrospectively as a case series study at Osmania General Hospital, Afzulgunj, Hyderabad over a period of 1 year from January 2017 - December 2017.

The demographic characteristic of the patient and the presenting complaints, the site of the lesion, size, its multicentricity and duration were recorded. Melanoma was determined according to Clark level. All the excised or biopsied specimens were processed for histopathological study. They were stained by routine haematoxylin and eosin stain. IHC was carried out using HMB-45 and S-100 where indicated.

\section{RESULTS}

A total of 31 cases were studied.

\begin{tabular}{|c|c|c|}
\hline Sl. No. & Diagnosis & $\begin{array}{c}\text { No. of } \\
\text { Cases (\%) }\end{array}$ \\
\hline 1 & Becker's nevus & $4(13)$ \\
\hline 2 & Nevus sebaceous & $4(13)$ \\
\hline 3 & Dermal nevus & $4(13)$ \\
\hline 4 & Compound nevus & $2(6.45)$ \\
\hline 5 & Seborrheic dermatitis & $3(9.6)$ \\
\hline 6 & Pigmented seborrheic keratosis & $1(3.2)$ \\
\hline 7 & Nevus spilus & $1(3.2)$ \\
\hline 8 & Linear verrucous epidermoid nevus & $1(3.2)$ \\
\hline 9 & Nevus hypermelanosis/ post- & $2(6.45)$ \\
\hline 10 & inflammatory hyperpigmentation & $1(3.2)$ \\
\hline 11 & Universal acquired melanosis & $3(9.6)$ \\
\hline 12 & Malignant melanoma & $4(13)$ \\
\hline \multicolumn{3}{|c|}{ Tigmented basal cell carcinoma } \\
\hline
\end{tabular}

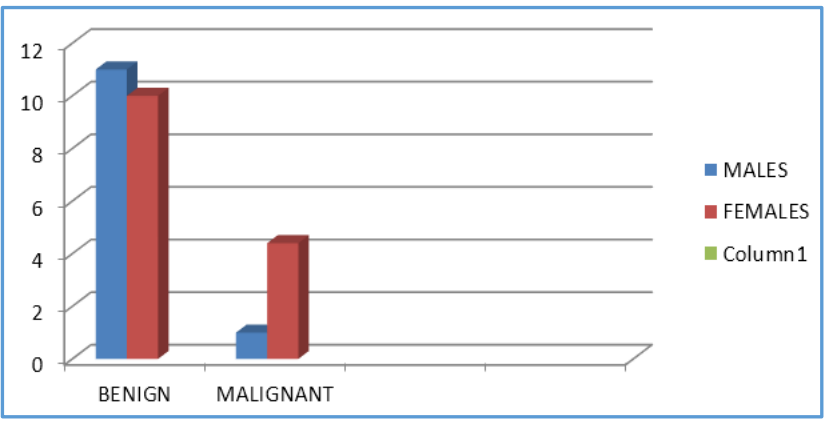

Figure 2. Sex Distribution

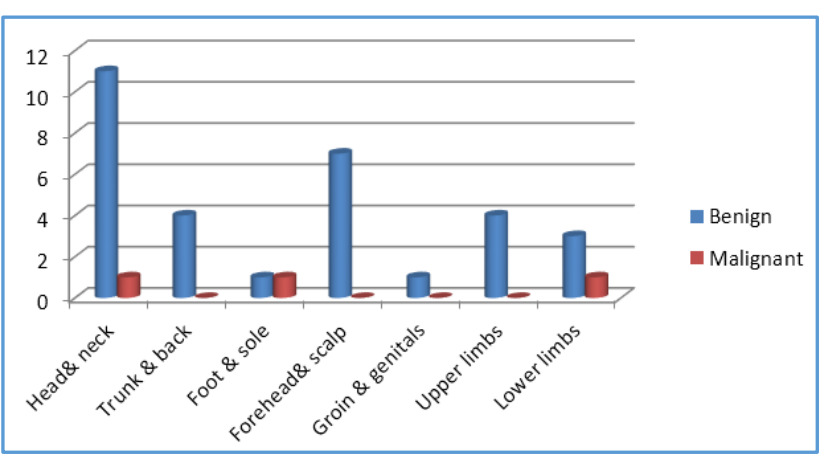

Figure 3. Site Distribution

In our study out of total 31 cases, benign pigmented lesions account for 25 cases (80\%) and malignant 6 cases (20\%) [Table 1]. Most common benign lesions were dermal nevus, nevus sebaceous and Becker's nevus. Malignant lesions included pigmented basal cell carcinoma and malignant melanoma. Benign lesions were more common in males, whereas female preponderance was seen in malignant lesions [Figure 2].

Most commonly involved sites were head and neck, forehead and scalp followed by upper extremities for benign lesions [Figure 3]. Patients presented usually with single elevated pigmented lesion, occasionally red erythematous lesion, itchy or scaling in benign lesions. Few lesions were present since birth. In case of malignancy, presentation was an ulcerated or pigmented nodular lesion which has been increasing in size over years. 


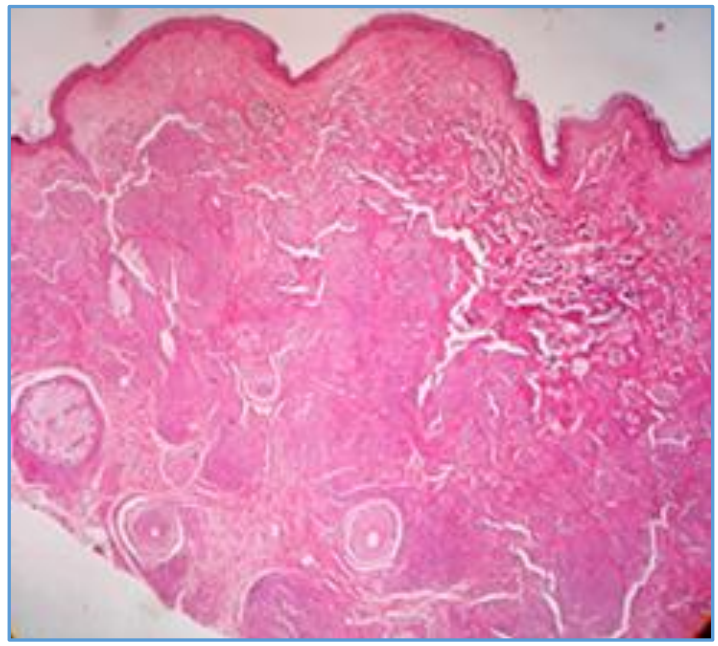

Figure 1. Dermal Nevus H and E 40X

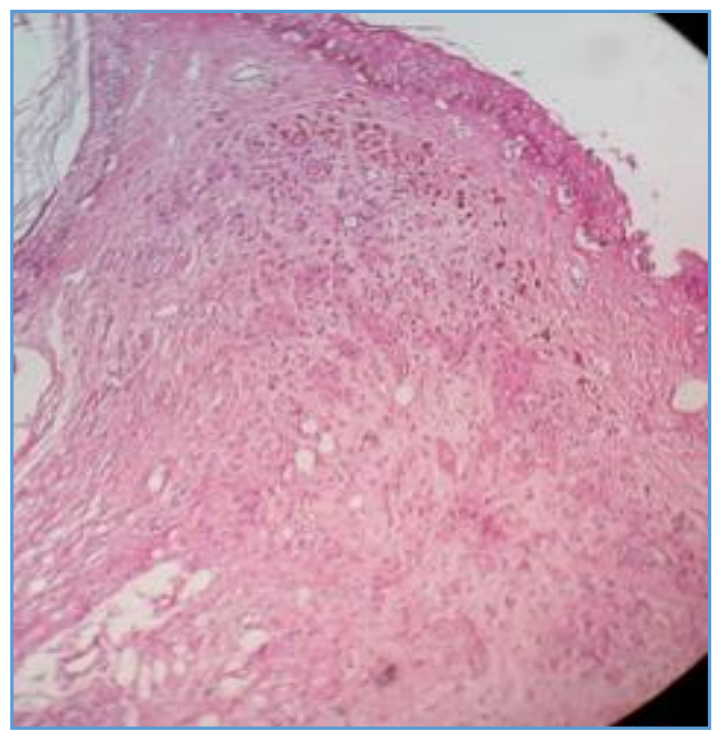

Figure 2. Compound Nevus H and E 40X

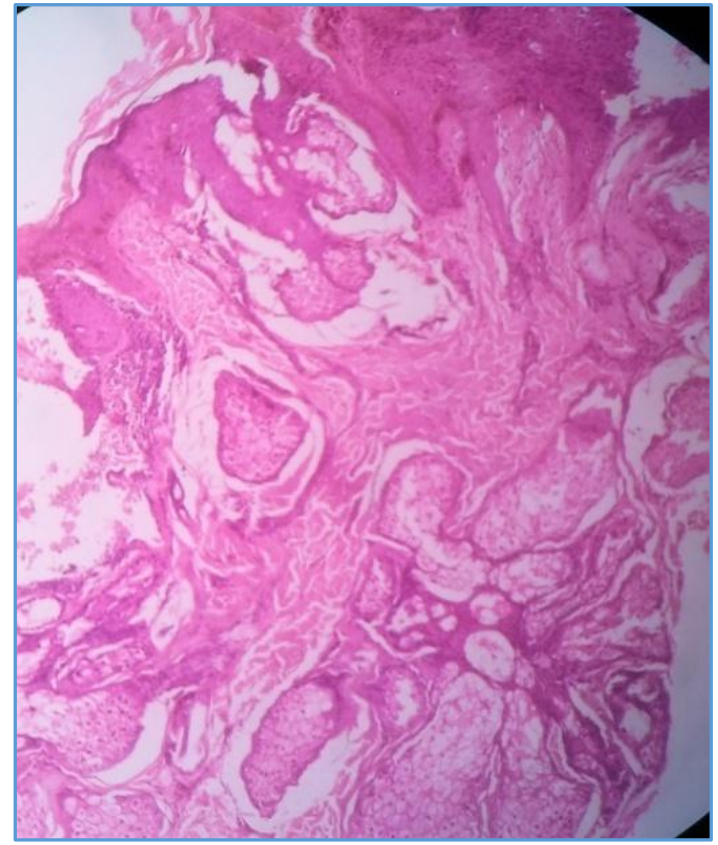

Figure 3. Nevus Sebaceous H and E 40X

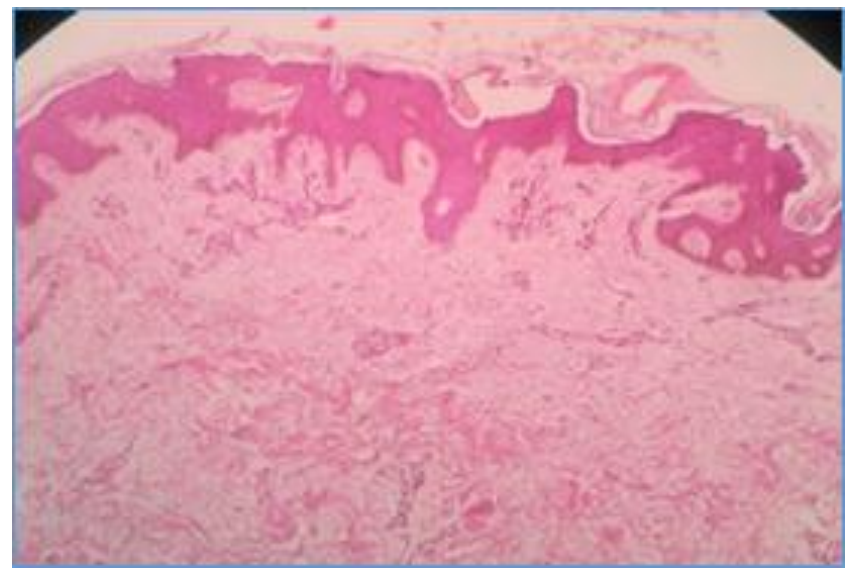

Figure 4. Becker's Nevus

H and $E$ 40X

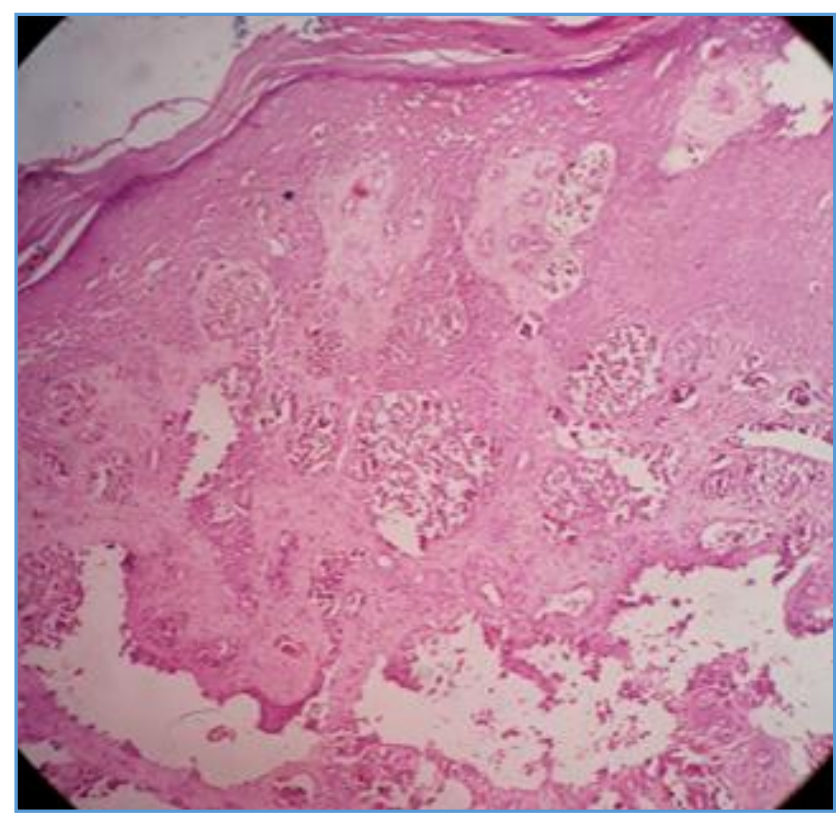

Figure 5. Malignant Melanoma H and $E$ 40X

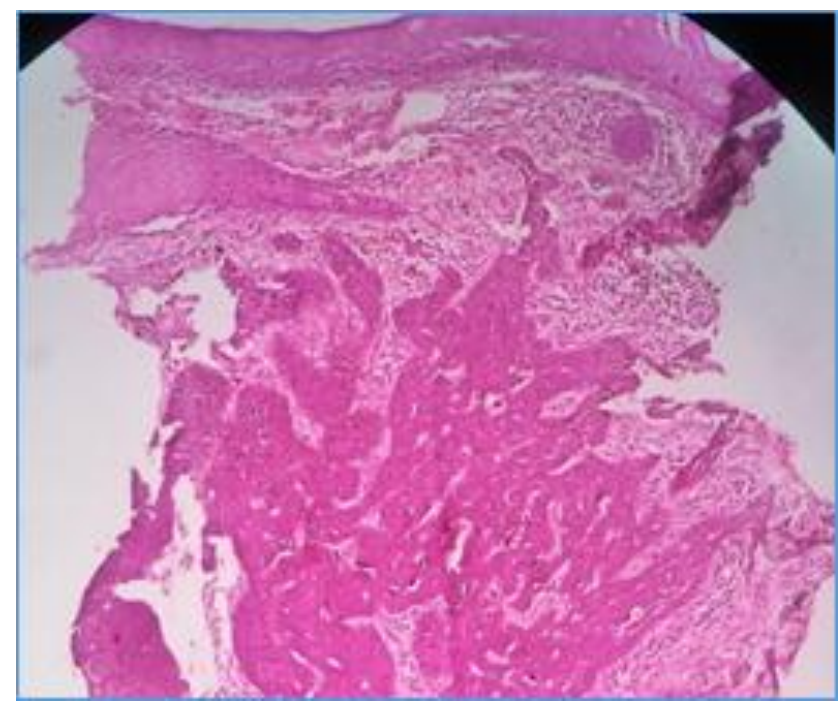

Figure 6. Pigmented Basal Cell Carcinoma H and $E 40 X$ 


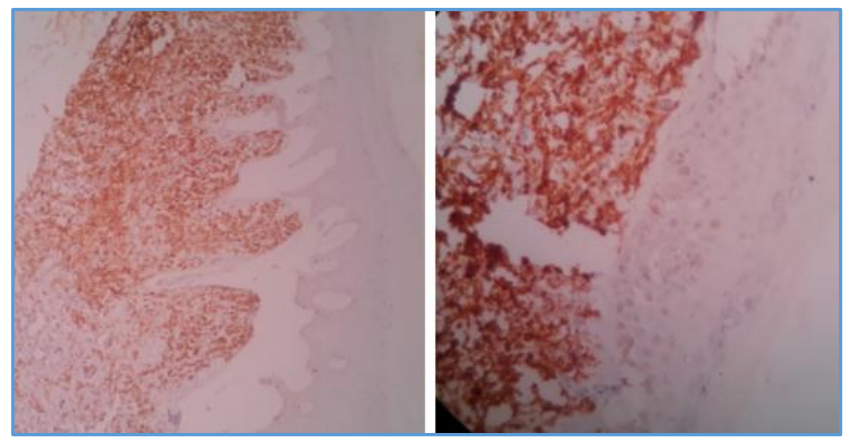

Figure 7. HMB-45 Positive-Malignant Melanoma H and $E 10 X$ and $40 X$

\section{DISCUSSION}

Malignant melanomas account for only $4 \%$ of all skin cancers; however, $>75 \%$ of all skin cancer related deaths worldwide, $[7,8]$ cutaneous malignant melanomas can occur de novo in a pre-existing nevus, therefore close examination of nevi is recommended.[9] The presence of dysplastic nevi considerably increase the risk of developing melanomas, which shows that these lesions are important risk markers beside being precursor to the disease.[10]

All the pigmented lesions in our study were divided into benign and malignant. The benign lesions included dermal nevus, nevus sebaceous, Becker's nevus, seborrheic keratosis, compound nevus and verrucous epidermal nevus. Malignant lesions include malignant melanoma and pigmented basal cell carcinoma. Our study is compared with three other studies done by Suvernakar et al, Nadia Shinaz et al, Crasta et al.

\begin{tabular}{|c|c|c|c|c|}
\hline & $\begin{array}{c}\text { Current } \\
\text { Study } \\
\text { (2017) }\end{array}$ & $\begin{array}{c}\text { Dr. } \\
\text { Suvernakar } \\
\text { et al (2014) }\end{array}$ & $\begin{array}{c}\text { Nadia Shinaz } \\
\text { et al } \\
\text { (2015) }\end{array}$ & $\begin{array}{c}\text { Crasta J } \\
\text { et al } \\
\text { (2002) }\end{array}$ \\
\hline $\begin{array}{c}\text { Study } \\
\text { Period }\end{array}$ & 1 yr. & 1 yr. & 10 yrs. & 2 yrs. \\
\hline $\begin{array}{c}\text { No. of } \\
\text { Cases }\end{array}$ & 31 & 44 & 338 & 26 \\
\hline Age Group & $10-68$ yrs. & $21-80$ yrs. & $50-70$ yrs. & $10-78$ yrs. \\
\hline M: F Ratio & $1: 1.2$ & $1: 1.1$ & $1.3: 1$ & $1: 1$ \\
\hline Site & $\begin{array}{c}\text { Head and } \\
\text { neck } \\
\text { (Benign) }\end{array}$ & $\begin{array}{c}\text { Head and } \\
\text { neck } \\
\text { (Benign) }\end{array}$ & $\begin{array}{c}\text { Face(benign) } \\
\text { Foot and soles } \\
\text { (Malignant) }\end{array}$ & $\begin{array}{c}\text { Face } \\
\text { (Benign) }\end{array}$ \\
\hline $\begin{array}{c}\text { Benign } \\
\text { Lesion }\end{array}$ & $\begin{array}{c}\text { Dermal } \\
\text { nevus } \\
\text { Seborrheic } \\
\text { keratosis }\end{array}$ & $\begin{array}{c}\text { Seborrheic } \\
\text { keratosis }\end{array}$ & $\begin{array}{c}\text { Compound } \\
\text { nevus; } \\
\text { Seborrheic } \\
\text { keratosis }\end{array}$ & $\begin{array}{c}\text { Seborrheic } \\
\text { keratosis }\end{array}$ \\
\hline \multicolumn{5}{|c|}{$\begin{array}{c}\text { Basal cell } \\
\text { carcinoma } \\
(13 \%) \\
\text { Malignant } \\
\text { Lesion }\end{array}$} \\
$\begin{array}{c}\text { Malignant } \\
\text { melanoma } \\
(6.45 \%)\end{array}$ & $\begin{array}{c}\text { BCC (6.45\%) } \\
\text { melanoma } \\
(12 \%)\end{array}$ & $\begin{array}{c}\text { Malignant } \\
\text { melanoma } \\
(8 \%)\end{array}$ & $\begin{array}{c}\text { Basal cell } \\
\text { carcinoma } \\
(46 \%)\end{array}$ \\
\hline \multicolumn{5}{|c|}{ Comparative Study } \\
\hline
\end{tabular}

Benign pigmented lesions in our study accounted for $80 \%$ and malignant $20 \%$. Suvernakar et al reported $84 \%$ benign and $16 \%$ malignant, whereas in Nadia et al and Crasta et al malignant lesions accounted for $8 \%$ and $46 \%$ respectively. In our study, benign lesions ranged from 10 - 60 years' age group and malignant 60 - 68 years. Suvernakar et al reported majority $(47.73 \%)$ were in the age group of 61 - 80 years followed by $22.73 \%$ in the age group of 21 - 40 years with male-to-female ratio of $1: 1.1$. Crasta et al reported incidence among 61 - 80 yrs. with a M: F ratio of 1.2: 1 .
Nadia et al reported incidence among 50 - 70 years' age. Suvernakar et al study revealed head and neck involvement in $63.64 \%$ cases, lower extremity in $22.73 \%$ and trunk in $13.64 \%$ cases. Crasta J et al reported head and neck involvement in $70 \%$ cases, trunk in $20 \%$ and lower extremity in $10 \%$ cases. Malignant melanoma, Clark's grading of malignant melanoma in our study revealed grade 4 and 5 . Basal cell carcinoma showed features of malignancy along with pigmentation. Histologically features of melanoma include ulceration, Breslow's depth of invasion in millimetres, mitotic activity (> 2/10 HPF) and tumour associated lymphocytic response.

Immunohistochemistry (IHC) using HMB-45 and S100 can be used to confirm. Distant metastasis is commonly found in the lungs, gastrointestinal tract, bone, liver and brain.

Multimodality treatment is given for treatment of melanoma which includes surgery, chemotherapy, radiotherapy and immunotherapy.

\section{CONCLUSION}

Histopathological interpretation of pigmented lesions of skin is useful to differentiate pigmented variants of nonmelanocytic lesions, as the removal of premalignant lesions will reduce the occurrence of malignant disease.

\section{REFERENCES}

[1] Suvernakar S, Harwani SR, Deshpande S. A clinicopathological study of pigmented skin lesions. IOSR Journal of Dental and Medical Sciences (IOSRJDMS) 2014;13(5):70-3.

[2] LeBoit PE, Burg G, Weedon D, et al. World Health Organisation of Tumors. Pathology and Genetics. Skin tumors. Lyon: IARC Press 2006: p. 49-118.

[3] Crasta J, Rameshkumar K. Pigmented lesions of nonmelanocytic origin - a pathological perspective. Indian J of Dermatol 2002:47(2):84-7.

[4] Abbasi NR, Shaw HM, Rigel DS, et al. Early diagnosis of cutaneous melanoma: revisiting the ABCD criteria. JAMA 2004;292(22):2771-6.

[5] Mukhopadhyay S, Ghosh S, Siddharta D, et al. A clinicopathological study of malignant melanoma with special reference to atypical presentation. Indian J Pathol Microbopl 2008;51(4):485-8.

[6] Kwok YK, Giam YC, Tan SH, et al. A retrospective study of melanocytic naevi at the National Skin Centre. Ann Acad Med Singapore 2001;30(1):32-7.

[7] American Cancer Society. Cancer facts and figures 2010. http://www.cancer.org/Research/Cancer Facts Figures/cancer-facts-and-figures-2010.

[8] Pappo AS. Melanoma in children and adolescents. Eur J Cancer 2003;39(18):2651-61.

[9] Skender-Kalenas TM, English DR, Heenan PJ. Benign melanocytic lesions: risk markers or precursors of cutaneous melanoma? J Am Acad Dermatol 1995;33(6):1000-07.

[10] Tsao H, Atkins MB, Sober AJ. Management of cutaneous melanoma. N Eng J Med 2004;351(10):9981012. 